\title{
The Control of Fusarium Root Rot and Development of Coastal Pine (Pinus thunbergii Parl.) Seedlings in a Container Nursery by Use of Bacillus licheniformis MH48
}

\author{
Sang-Jae Won ${ }^{1}$, Vantha Choub ${ }^{1}$, Jun-Hyeok Kwon ${ }^{1}$, Dong-Hyun Kim ${ }^{2}{ }^{\mathbb{D}}$ and \\ Young-Sang Ahn ${ }^{1, *(1)}$ \\ 1 Division of Forest Resources, Chonnam National University, Gwangju 61186, Korea; \\ lazyno@naver.com (S.-J.W.); vanthachoub@gmail.com (V.C.); wg6102@naver.com (J.-H.K.) \\ 2 Department of Fire Safety Engineering, Jeonju University, Jeollabuk-do 55069, Korea; \\ 72donghyunkim@jj.ac.kr \\ * Correspondence: ysahn@jnu.ac.kr; Tel.: +82-62-530-2081; Fax: +82-62-530-2089
}

Received: 19 November 2018; Accepted: 20 December 2018; Published: 22 December 2018

\begin{abstract}
This study investigated the control of Fusarium root rot and development of coastal pine (Pinus thunbergii) seedlings in a container nursery by using Bacillus licheniformis MH48. High-quality seedlings without infectious diseases cause vigorous growth. Fusarium root rot caused by Fusarium oxysporum is responsible for serious damage to coastal pine seedlings in nurseries. B. licheniformis MH48 produced enzymes that degraded the fungal cell walls, such as chitinase and $\beta$-1,3-glucanase. These lytic enzymes exhibited destructive activity toward F. oxysporum hyphae, which were found to play key roles in the suppression of root rot. In addition, B. licheniformis MH48 increased the nitrogen and phosphorus in soils via fixed atmospheric nitrogen and solubilized inorganic phosphate. B. licheniformis MH48 produced the phytohormone auxin, which stimulated seedling root development, resulting in increased nutrient uptake in seedlings. Both the bacterial inoculation and the chemical fertilizer treatments significantly increased seedling growth and biomass, and the bacterial inoculation had a greater effect on seedling development. Based on the results from this study, B. licheniformis MH48 showed potential as a biological agent against Fusarium root rot and as a promoter of growth and development of Pinus thunbergii seedlings.
\end{abstract}

Keywords: antagonistic bacteria; lytic enzyme; root rot pathogen; auxin; seedling development; container nursery

\section{Introduction}

Coastal pine (Pinus thunbergii Parl.), which can tolerate drought and salt stress, grows well in sandy soil and in full sun and is an important tree in the coastal forests that are widespread in Northeastern Asia [1-4]. Several studies on understanding the process and mechanisms of establishing coastal pine forests, as well as reforestation projects, have been initiated, with the goal of recovering and maintaining coastal pine forests [1-5]. Coastal forests growing along the shoreline can help reduce the devastating impact of a tsunami and storm surge by decreasing their wave energies [6]. In addition, they provide a variety of services for coastal ecology and societies, including wildlife habitat [7], water-quality control [8], and shelter for people [9].

In a recent forest restoration project, container seedlings have mostly replaced bare-root seedlings [10-12]. Container seedlings promote early growth after outplanting by reducing shock and providing better seedling health and a better survival rate [11]. However, the production of seedlings 
using containers can cause defects, such as nutritional imbalances [13]. In addition, excessive use of chemical fertilizers in forest nursery production damages soil microorganisms, affects the fertility of soil, decreases plant growth, and pollutes the environment [14-16]. In particular, nitrogen fertilizer tends to substantially increase the proportion of fungal pathogenic genera, thus worsening plant health [17]. The container seedlings are often exposed to persistent pathogenic attacks, particularly those inciting root rot, at primary stages of seedling establishment. Root rot in container-grown conifers such as spruce and pine is a major problem [18-20]. During a nursery survey in this study, root rot incited by Fusarium oxysporum was found in coastal pine seedlings, and many seedlings wilted and died (Figure 1). Given the highly devastating nature of root rot pathogens, effective disease management is essential to raise healthy forest seedlings for the successful implementation of reforestation and afforestation. Fungicide use has been adopted by nursery growers to reduce the incidence of root rot, but the disease continues to pose a serious threat to seedlings [21]. In addition, many chemical products, including fertilizers and fungicides, deplete nonrenewable resources and pose hazards to humans and the environment [22,23]. Therefore, interest in environmentally friendly practices in forest seedling production systems has recently focused on promoting seedling development.

A. 1-year seedlings (July 2014)

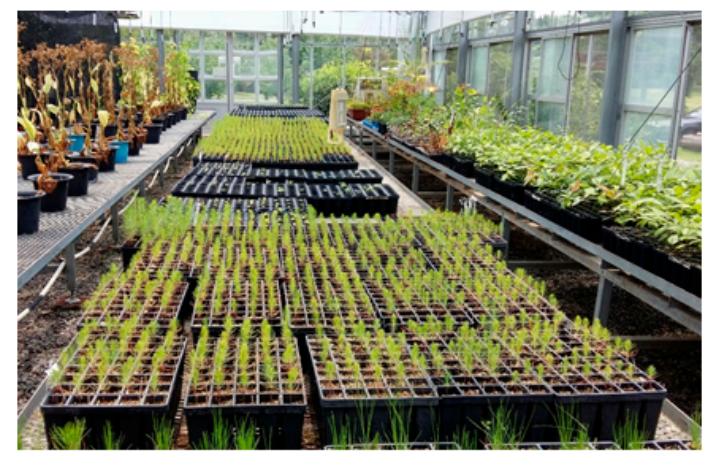

C. Seedlings infected by root rot

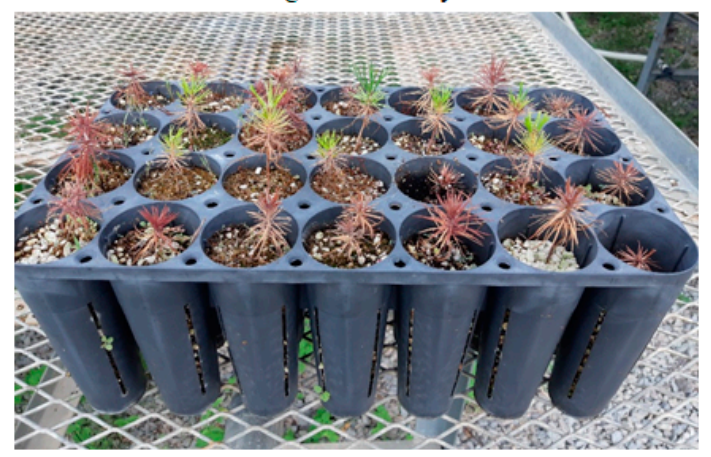

B. 2-year seedlings (July 2015)

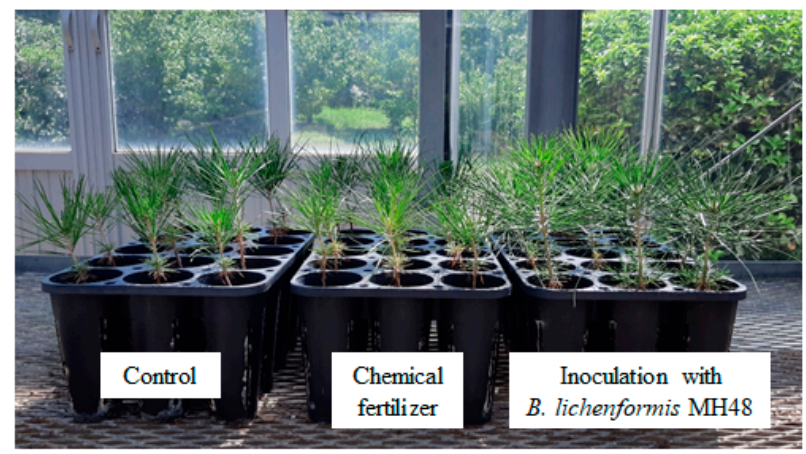

D. Root growth in seedlings

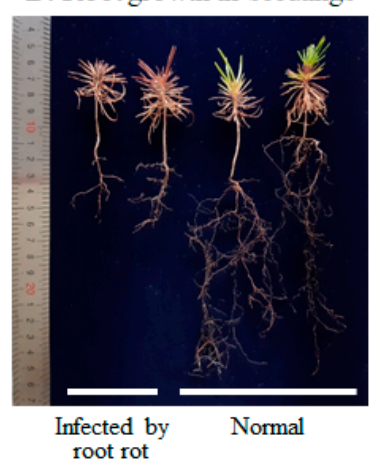

Figure 1. Study area $(\mathbf{A})$ and seedling growth $(\mathbf{B})$ of coastal pine in an experimental greenhouse at the forest nursery. Seedlings infected with Fusarium root rot wilted and died (C), and root growth was reduced $(\mathbf{D})$.

Plant growth-promoting rhizobacteria (PGPR) are beneficial native soil bacteria that are an environmentally sound way of increasing plant yields by facilitating plant growth through either a direct or an indirect mechanism [24-40]. The direct promotion of plant growth by PGPR provides the plant with phytohormones [24-26], which facilitate the uptake of nutrients from the soils $[24,25,27,28]$ and help establish a symbiosis with rhizobia or mycorrhiza [29]. The indirect promotion of plant growth occurs when PGPR lessen or prevent the deleterious effects of pathogenic organisms [30-37], nematodes, and insects [38-40] by producing antagonistic substances, such as hydrolytic enzymes, including chitinases, glucanases, proteases, and lipases. The Bacillus species is one of the most important microorganisms in PGPR and is isolated from rhizosphere soil $[25,26,34,37,39,41]$. 
The benefits of Bacillus licheniformis strains include the production of plant hormones, such as auxin and gibberellin, nitrogen fixation, and the solubilization of inorganic phosphate, which lead to increased forest seedling growth and yield [24-26]. In addition, B. licheniformis strains are bioenhancers that stimulate fine-root development and promote nutrient uptake in forest seedlings [24]. However, to date, the effects of lytic enzymes derived from B. licheniformis strains on fungal pathogens remain poorly understood.

Forestry has studied many bacterial species that act as PGPR, described in the literature as being successful in the biological control of diseases [18-20,42] and for improving plant growth [24-26,29,43-46]. However, studies of PGPR being used simultaneously for biological disease control and tree-growth promotion are rarely described in forestry. The increasing demand for forestry production with a significant reduction of synthetic chemical fertilizer and fungicide use is a big challenge currently. The rapid early growth of healthy, infection-free forest seedlings is closely related to the success of plantation establishment [47] because after planting, when they compete for resources with weeds, large seedlings perform better than small seedlings [48,49]. To produce high-quality coastal pine seedlings for the construction of coastal pine forests, it is very important to understand the effects of PGPR on the development of these seedlings in a container nursery. The objective of this study was to investigate the control of Fusarium root rot and growth promotion of coastal pine seedlings in a container forest nursery by using B. licheniformis MH48.

\section{Materials and Methods}

\subsection{Antagonistic Activity of B. licheniformis MH48 against F. oxysporum}

The bacterial strains of B. licheniformis MH48 were isolated from rhizosphere soil in a coastal area of Korea $[25,26,39,41]$. This bacterial strain was obtained from the laboratory of soil microbiology, Chonnam National University, Korea. During a nursery experiment in this study, coastal pine seedlings had rotten roots and died (Figure 1C). According to the Korean Agriculture Culture Collection (KACC; Suwon, Korea), F. oxysporum was found in dead seedlings of coastal pines. Fungal pathogen F. oxysporum was purchased from KACC for antagonistic activity experiments with B. licheniformis MH48.

For the control experiment of Fusarium root rot from F. oxysporum with lytic enzymes of B. licheniformis $\mathrm{MH} 48$, the latter was cultured in $1 \mathrm{~L}$ of broth medium and incubated at $30{ }^{\circ} \mathrm{C}$ for 7 days. The composition (per liter) for the broth medium was urea $\left(\left(\mathrm{NH}_{2}\right)_{2} \mathrm{CO}\right)(1.7 \mathrm{~g})$, potassium phosphate monobasic $\left(\mathrm{KH}_{2} \mathrm{PO}_{4}\right)(0.4 \mathrm{~g})$, potassium chloride $(\mathrm{KCl})(0.08 \mathrm{~g})$, organic compost $(1.0 \mathrm{~g})$, and sugar (2.2 g). Growth of B. licheniformis MH48 was examined for the required cell density (10 ${ }^{7}$ colony forming units (CFU) $\mathrm{mL}^{-1}$ ) and checked for contamination before application [25].

The antagonistic activity of B. licheniformis MH48 against F. oxysporum was measured by the dual culture method. A potato dextrose agar (PDA) medium was prepared, B. licheniformis MH48 was streaked onto one side of each agar plate, and a fungal agar plug of $5 \mathrm{~mm}$ in diameter was made using a sterile cork borer and placed on the other side of the inoculated plates. A plate inoculated with the fungal pathogen alone was used as the control. Three replicates of each plate were incubated at $30^{\circ} \mathrm{C}$ for 7 days, and the proportion of B. licheniformis MH48 inhibiting the growth of the fungal pathogen F. oxysporum was calculated using the formula [50]: inhibition (\%) $=\left(\left(R_{1}-R_{2}\right) / R_{1}\right) \times 100$, where $R_{1}$ is the radial growth of F. oxysporum in the control plate, and $R_{2}$ is the radial growth of F. oxysporum in the dual culture plate.

\subsection{Production of the Defense-Related Lytic Enzymes by B. licheniformis MH48}

To examine chitinase and $\beta$-1,3-glucanase activities, B. licheniformis MH48 was cultured on the medium at $30^{\circ} \mathrm{C}$ for 7 days, and the bacterial supernatant was collected daily. To assay the chitinase activity, a reaction mixture consisting of $50 \mu \mathrm{L}$ of bacterial culture, $450 \mu \mathrm{L}$ of $50 \mathrm{mM}$ sodium acetate buffer ( $\mathrm{pH} 5.0$ ), and $500 \mu \mathrm{L}$ of a $0.5 \%$ colloidal chitin solution was incubated at $37{ }^{\circ} \mathrm{C}$ for $1 \mathrm{~h}$ [51]. The reaction was terminated by adding $200 \mu \mathrm{L}$ of $1 \mathrm{~N} \mathrm{NaOH}$ and centrifuged at 12,000 rpm for $10 \mathrm{~min}$ 
at $4{ }^{\circ} \mathrm{C}$. The supernatant $(500 \mu \mathrm{L})$ was mixed with $1 \mathrm{~mL}$ of Schales' reagent and boiled for $15 \mathrm{~min}$ at $100{ }^{\circ} \mathrm{C}$ in a water bath. Absorbance was measured at $420 \mathrm{~nm}$ by a UV spectrophotometer. One unit of chitinase activity was defined as the reducing activity that releases $1 \mu \mathrm{mol}$ of $N$-acetylglucosamine per hour at $37^{\circ} \mathrm{C}$.

To measure the $\beta-1,3$-glucanase activity, a reaction mixture containing $50 \mu \mathrm{L}$ of bacterial culture, $50 \mu \mathrm{L}$ of laminarin $\left(10 \mathrm{mg} \mathrm{mL}^{-1}\right)$, and $400 \mu \mathrm{L}$ of $50 \mathrm{mM}$ of a sodium acetate buffer (pH 5.0) was incubated at $37^{\circ} \mathrm{C}$ for $1 \mathrm{~h} \mathrm{[52].} \mathrm{The} \mathrm{reaction} \mathrm{was} \mathrm{stopped} \mathrm{by} \mathrm{adding} 1.5 \mathrm{~mL}$ of dinitrosalicylic acid (DNS) reagent and boiling in a water bath for $5 \mathrm{~min}$. Absorbance at $550 \mathrm{~nm}$ was used to measure the concentration of reducing sugars. One unit of $\beta-1,3$-glucanase activity was defined as the amount of enzyme that catalyzes the release of $1 \mu \mathrm{mol}$ of glucose per hour at $37^{\circ} \mathrm{C}$.

\subsection{Effect of Lytic Enzymes Produced from B. licheniformis MH48 on the Mycelial Morphology of F. oxysporum}

To examine how much the lytic enzymes, including chitinase and $\beta-1,3$-glucanase, from B. licheniformis MH48 inhibited F. oxysporum mycelia growth, $1 \mathrm{~mL}$ of $F$. oxysporum culture was grown on a potato dextrose broth (PDB) medium at $30^{\circ} \mathrm{C}$ for 3 days. F. oxysporum mycelia were observed under a light microscope (Olympus BX41TF, Tokyo, Japan). All observations of morphological mycelia were performed in triplicate.

\subsection{Plant Material and Experimental Conditions}

The coastal pine seeds used in this study were obtained in December 2013 from the National Forest Seed Variety Center of Korea and stored at $4{ }^{\circ} \mathrm{C}$ in a cool refrigerator with a constant relative humidity of $40 \%$. To interrupt their dormancy, these seeds were dipped in running tap water for 7 days. Seeds were sown at $1 \mathrm{~cm}$ depth of growth media in each container (volume $500 \mathrm{~mL}$ ). The seedling tray was $25 \mathrm{~cm}$ wide, $41 \mathrm{~cm}$ long, and $16 \mathrm{~cm}$ high, and included 15 cells with a $7.5 \mathrm{~cm}$ diameter and $16 \mathrm{~cm}$ height (Figure 1B). Seedling emerged in March 2014, approximately 1 month after sowing seeds in February 2018. The peat was turfy peat with a medium structure, and the perlite was coarse (peat/perlite $=5: 1$ ). After the peat and perlite were mixed, the growth medium was sieved to $5 \mathrm{~mm}$, and the containers were manually filled with approximately $500 \mathrm{~mL}$ substrate.

The experiment was carried out with three replications in a greenhouse with an automatic spray irrigation system at the forest nursery at Chonnam National University (approximately $35^{\circ} 17^{\prime} \mathrm{N}$ latitude, $126^{\circ} 90^{\prime} \mathrm{E}$ longitude) (Figure 1). The experiment was conducted in a greenhouse, with the temperature kept at $20-25{ }^{\circ} \mathrm{C}$ all day long using a heating and cooling system. The light condition was natural. The following three treatments were used: control (without fertilizer or bacteria), a chemical fertilizer, and B. licheniformis MH48 inoculation. Each treatment involved 45 seedlings (15 seedlings for each replication), and a total of 135 container seedlings were used in the experiment. During the 12 months of growth in the experimental period from March 2014 to February 2015, normal management practices were carried out, but no fertilization or bacterial inoculation was applied. From March 2015 to February 2016, the container seedlings were treated with chemical fertilizer or B. licheniformis MH48 inoculation at two-week intervals. The bacterial inoculation $(10 \mathrm{~L}$ of B. licheniformis MH48 culture) and the chemical fertilizer (solved urea (17.0 g), potassium phosphate monobasic $(40.0 \mathrm{~g})$, and potassium chloride $(8.0 \mathrm{~g})$ in $10 \mathrm{~L}$ of water) were added to $10 \mathrm{~L}$ of water and were applied to the soil adjacent to the roots. The fertilizer application rate was based on the recommended basal chemical fertilizer application rate for coniferous seedlings in the nursery of the Korea Forest Service [53].

\subsection{Growth Medium, Plant Sampling, and Measurement}

In February 2016, the growth media were mixed in each replication, and samples $(n=9)$ were taken from each replication and oven-dried at $105^{\circ} \mathrm{C}$ for $24 \mathrm{~h}$. 
After we carefully washed the root systems to eliminate all media, the seedling growth parameters were measured, including shoot and root lengths, root collar diameter, and seedling biomass (shoot and root dry mass) $(n=135)$. The biomass was measured after drying the separated shoots and roots at $105{ }^{\circ} \mathrm{C}$ for $24 \mathrm{~h}$. The shoots and roots were separated at the boundary of the uppermost part of the root. Additionally, based on the five selected seedlings of average growth that were measured for each treatment $(n=15)$, measurements were taken of the total nitrogen and total phosphorus of the seedlings $(n=45)$. For the calculation of the nutrient content of the seedlings, the following formula was used $[25,26]$ : nutrient content $(\mathrm{mg})=(($ dry weight $(\mathrm{g}) \times$ nutrient concentration $(\%))$.

The total nitrogen content of the growth media was calculated by the Kjeldahl method [54] after wet digestion with $\mathrm{H}_{2} \mathrm{SO}_{4}$. The total nitrogen content of the seedlings was analyzed using an elemental analyzer (Variomax CN Analyzer, Elementar Analysensysteme GmbH, Germany) with a thermal conductivity detector (TCD) after combustion at $1200{ }^{\circ} \mathrm{C}$ with nitrogen and helium. After digestion in nitric acid in a microwave oven (MARS Xpress, CEM Corporation, Matthews, NC, USA), the total phosphorus content in the growth media and seedling samples was measured using an ICP-OES (Optima 8300, PerkinElmer, Waltham, MA, USA).

\subsection{Statistical Analysis}

The data were subjected to an analysis of variance (ANOVA) using the SPSS statistics program (version 21; Chicago, IL, USA). The mean values were compared using a Least Significant Difference (LSD) test at a significance level of $p<0.05$, and the results are reported as the mean \pm standard deviation. Variables of seedling nutrient concentration, shoot length, root length, total height, and root dry mass were log-transformed to stabilize the variance.

\section{Results}

\subsection{Control of B. licheniformis MH48 against Fusarium Root Rot Disease}

\subsubsection{Production of Lytic Enzymes by B. licheniformis MH48}

The production of lytic enzymes, such as chitinase and $\beta-1,3$-glucanase activities, was examined from the bacterial culture of B. licheniformis MH48 (Figure 2). The chitinase activity gradually increased for five days, eventually reaching a maximum value of 428.30 units $\mathrm{mL}^{-1}$. Thereafter, the chitinase activity rapidly decreased (Figure 2A). The $\beta$-1,3-glucanase activity slowly increased for three days, eventually reaching a maximum value of 15.25 units $\mathrm{mL}^{-1}$ of the growth of F. oxysporum.

A. Changes of chitinase activity

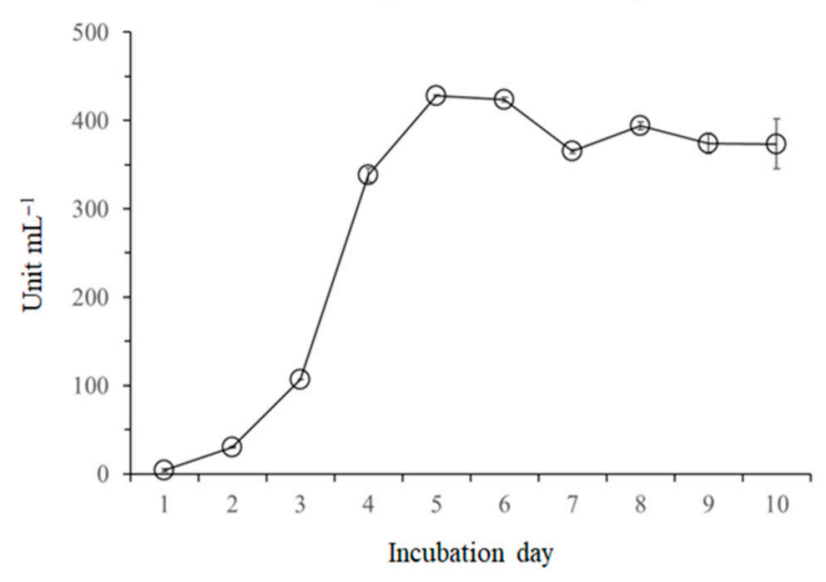

Figure 2. Cont. 
B. Changes of $\beta$-1,3-glucanase activity

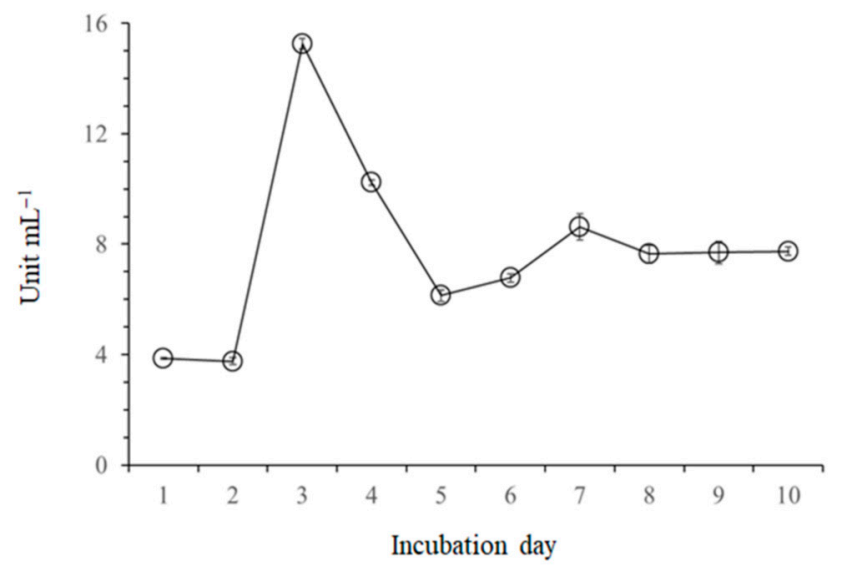

Figure 2. Changes in chitinase activity (A) and $\beta$-1,3-glucanase activity (B) in the culture of B. licheniformis MH48. Error bars represent the standard deviation of three replications.

The hyphae of F. oxysporum incubated without B. licheniformis MH48 as the control showed normal morphology under the light microscope (Figure 3A). However, the hyphae of four foliar fungal pathogens incubated with B. licheniformis MH48 showed mycelial abnormalities, such as degradation, deformation, and lysis (Figure 3B).

A. Control

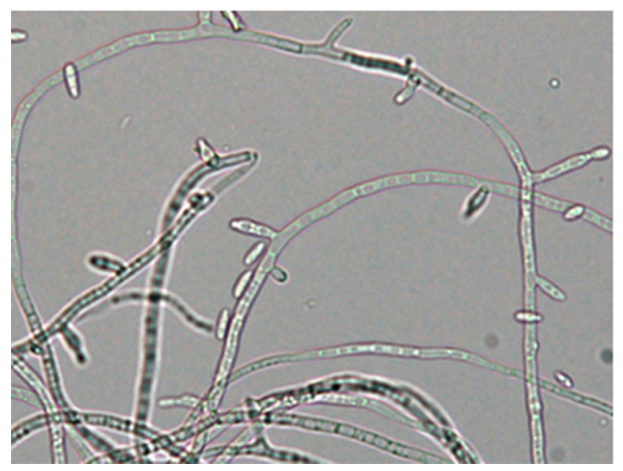

B. B. lichniformis MH48

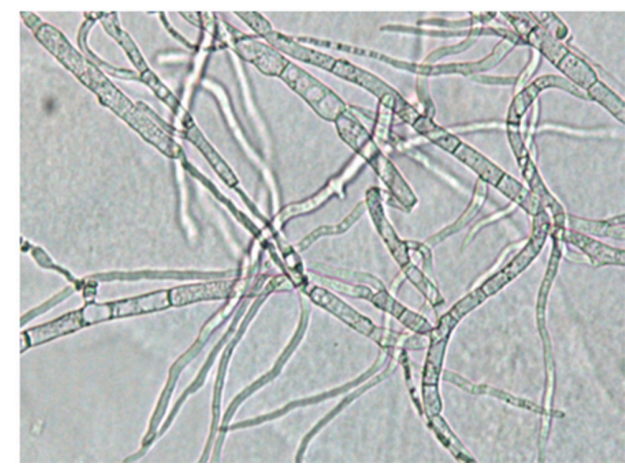

Figure 3. Effect of chitinase and $\beta$-1,3-glucanase produced by B. licheniformis MH48 on hyphal deformation of F. oxysporum (B) and the control (A) under light microscope.

3.2. Effects of Inoculation with B. licheniformis MH48 on the Development of Coastal Pine Seedlings

\subsubsection{Nutrient Contents of the Growing Media}

The total nitrogen content was between 0.15 and $0.21 \mathrm{~g} \mathrm{~kg}^{-1}$, and for the control, chemical fertilizer, and inoculation with B. licheniformis MH48 treatments, the total phosphorus content ranged from 0.05 to $0.06 \mathrm{~g} \mathrm{~kg}^{-1}$ in the growth media (Table 1). The total nitrogen contents of the growth media were significantly lower $(p<0.05)$ after the treatment with bacterial inoculation when compared to both chemical fertilizer and control treatments (Table 1). Bacterial inoculation and chemical fertilizer treatments had no significant effect $(p>0.05)$ on the total phosphorus contents of the growth media (Table 1). 
Table 1. Total nitrogen and total phosphorus contents of growth media and concentrations and contents of total nitrogen and total phosphorus in coastal pine seedlings for the control, chemical fertilizer, and inoculation with B. licheniformis MH48 treatments.

\begin{tabular}{|c|c|c|c|c|c|c|}
\hline \multirow{2}{*}{ Treatment } & \multicolumn{2}{|c|}{$\begin{array}{c}\text { Growth Media } \\
\text { Nutrient Content }\left(\mathrm{g} \mathrm{kg}^{-1}\right)\end{array}$} & \multicolumn{2}{|c|}{$\begin{array}{c}\text { Seedling } \\
\text { Nutrient Concentration }(\%)\end{array}$} & \multicolumn{2}{|c|}{$\begin{array}{c}\text { Seedling } \\
\text { Nutrient Content (mg) }\end{array}$} \\
\hline & $\begin{array}{c}\text { Total } \\
\text { Nitrogen }\end{array}$ & $\begin{array}{c}\text { Total } \\
\text { Phosphorus }\end{array}$ & $\begin{array}{c}\text { Total } \\
\text { Nitrogen }\end{array}$ & $\begin{array}{c}\text { Total } \\
\text { Phosphorus }\end{array}$ & $\begin{array}{c}\text { Total } \\
\text { Nitrogen }\end{array}$ & $\begin{array}{c}\text { Total } \\
\text { Phosphorus }\end{array}$ \\
\hline Control & $0.21 \pm 0.04 \mathrm{a}$ & $0.05 \pm 0.02$ & $0.69 \pm 0.15 c$ & $0.15 \pm 0.05 b$ & $17.04 \pm 5.07 \mathrm{~b}$ & $3.67 \pm 1.36 b$ \\
\hline Chemical fertilizer & $0.20 \pm 0.02 \mathrm{a}$ & $0.05 \pm 0.01$ & $1.41 \pm 0.16 \mathrm{a}$ & $0.23 \pm 0.03 \mathrm{a}$ & $46.62 \pm 13.03 \mathrm{a}$ & $7.65 \pm 2.38 \mathrm{a}$ \\
\hline Bacterial inoculation & $0.15 \pm 0.01 b$ & $0.06 \pm 0.01$ & $1.07 \pm 0.15 b$ & $0.23 \pm 0.03 \mathrm{a}$ & $42.06 \pm 12.21 \mathrm{a}$ & $9.24 \pm 2.81 \mathrm{a}$ \\
\hline
\end{tabular}

Note: Means within each column with the same letter are not significantly different from each other according to the least significant difference test (LSD) at the $p<0.05$ level.

\subsubsection{Seedling Growth and Biomass}

The total height of the coastal pine seedlings for the three treatments ranged from 29.07 to $37.04 \mathrm{~cm}$, and the root-collar diameter ranged from 3.38 to $4.01 \mathrm{~mm}$ (Table 2). The total height and the root-collar diameter of the coastal pine seedlings inoculated with B. licheniformis MH48 were significantly higher $(p<0.05)$ than in the chemical fertilizer or control (Table 2). In the chemical fertilizer treatment, the root-collar diameter was significantly higher than in the control treatment, whereas total height was not significantly different from that of the control (Table 2).

Table 2. Growth and biomass production of coastal pine seedlings for the control, chemical fertilizer, and inoculation with $B$. licheniformis MH48 treatments.

\begin{tabular}{|c|c|c|c|c|c|c|c|}
\hline \multirow[b]{2}{*}{ Treatment } & \multicolumn{4}{|c|}{ Seedling Growth } & \multicolumn{3}{|c|}{ Seedling Biomass } \\
\hline & $\begin{array}{l}\text { Shoot Length } \\
\text { (cm) }\end{array}$ & $\begin{array}{l}\text { Root Length } \\
\text { (cm) }\end{array}$ & $\begin{array}{l}\text { Total Height } \\
\text { (cm) }\end{array}$ & $\begin{array}{c}\text { Root Collar } \\
\text { Diameter (mm) }\end{array}$ & $\begin{array}{l}\text { Shoot Dry } \\
\text { Mass (g) }\end{array}$ & $\begin{array}{l}\text { Root Dry } \\
\text { Mass (g) }\end{array}$ & $\begin{array}{l}\text { Total Dry } \\
\text { Mass (g) }\end{array}$ \\
\hline Control & $15.23 \pm 3.23 c$ & $13.81 \pm 2.15 b$ & $29.04 \pm 4.18 b$ & $3.38 \pm 0.32 c$ & $1.99 \pm 0.34 \mathrm{c}$ & $0.45 \pm 0.14 b$ & $2.44 \pm 0.45 c$ \\
\hline Chemical fertilizer & $19.10 \pm 2.38 \mathrm{~b}$ & $11.73 \pm 1.96 \mathrm{c}$ & $30.83 \pm 2.36 \mathrm{~b}$ & $3.62 \pm 0.34 \mathrm{~b}$ & $2.85 \pm 0.48 \mathrm{~b}$ & $0.47 \pm 0.12 b$ & $3.32 \pm 0.55 \mathrm{~b}$ \\
\hline Bacterial inoculation & $21.10 \pm 3.86 \mathrm{a}$ & $15.94 \pm 1.96 \mathrm{a}$ & $37.04 \pm 4.85 \mathrm{a}$ & $4.01 \pm 0.48 \mathrm{a}$ & $3.40 \pm 0.56 \mathrm{a}$ & $0.57 \pm 0.12 \mathrm{a}$ & $3.97 \pm 0.64 \mathrm{a}$ \\
\hline
\end{tabular}

Note: Means within each column with the same letter are not significantly different from each other according to

the least significant difference test (LSD) at the $p<0.05$ level.

Compared to the control, the bacterial inoculation and chemical fertilizer treatments had a more significant influence on the shoot, root, and total dry mass of the coastal pine seedlings (Table 2). The seedling biomass production of inoculation with B. licheniformis MH48 was greater than of chemical fertilizer, which was greater than that of control treatments. In particular, compared to the biomass of the control seedlings, the shoot, root, and total dry mass of the coastal pine seedlings grown in the bacterial inoculation were higher by $171 \%, 127 \%$, and $162 \%$, respectively. Clearly, the superior nutrients afforded by bacterial inoculation and chemical fertilizer generated significant seedling biomass, and the bacterial inoculation treatment was especially favorable to the coastal pine seedling biomass (Table 2).

\subsubsection{Seedling Nutrient Concentration and Content}

The concentration and content of total nitrogen and total phosphorus in the coastal pine seedlings treated with chemical fertilizers or inoculated with B. licheniformis MH48 were significantly higher than those of the control (Table 1). Except for the total nitrogen concentration in the seedlings, the nutrient concentrations and contents of the seedlings did not significantly differ between the chemical fertilizer and bacterial inoculation (Table 1). The total nitrogen and total phosphorus concentrations of the seedlings in chemical fertilizers and bacterial inoculation were $155 \%-204 \%$ and $153 \%$ higher than those in the control, respectively, and the total nitrogen and total phosphorus content by seedlings which received chemical fertilizers and bacterial inoculation were $247 \%-274 \%$ and $208 \%-252 \%$ greater than those in the control, respectively (Table 1). 
The highest growth and biomass ( $37.04 \mathrm{~cm}$ and $3.96 \mathrm{mg}$, respectively) of the seedlings were observed for the bacterial inoculation, which had a high nutrient content, while lower values $(29.07 \mathrm{~cm}$ and $2.44 \mathrm{mg}$, respectively) were observed in the control, which had the lowest nutrient content (Tables 1 and 2).

\section{Discussion}

In the chemical fertilizer treatment, several seedlings wilted and showed low growth (Figure 1B). This finding suggests that chemical fertilizers, especially nitrogen fertilizers, tend to substantially increase the proportion of fungal pathogens and harm plant health [17]. However, root rot of coastal pine seedlings by F. oxysporum was not shown in the bacterial inoculation treatment (Figure 1B) because B. licheniformis MH48 secretes chitinase and $\beta-1,3$-glucanase that can degrade chitin and $\beta-1,3$-glucan, respectively (Figure 2). Chitin and $\beta-1,3$-glucan are major components of fungal cell walls [30]. The hyphae of $F$. oxysporum incubated with B. licheniformis MH48 showed mycelial abnormalities, such as degradation, deformation, and lysis (Figure 3B). B. licheniformis MH48 showed strong inhibition against target pathogen F. oxysporum (Figure 4). Several studies have shown that antagonistic bacteria are an important source of the lytic enzymes that can prevent the dissemination and lower the virulence of fungal pathogens [30-37].
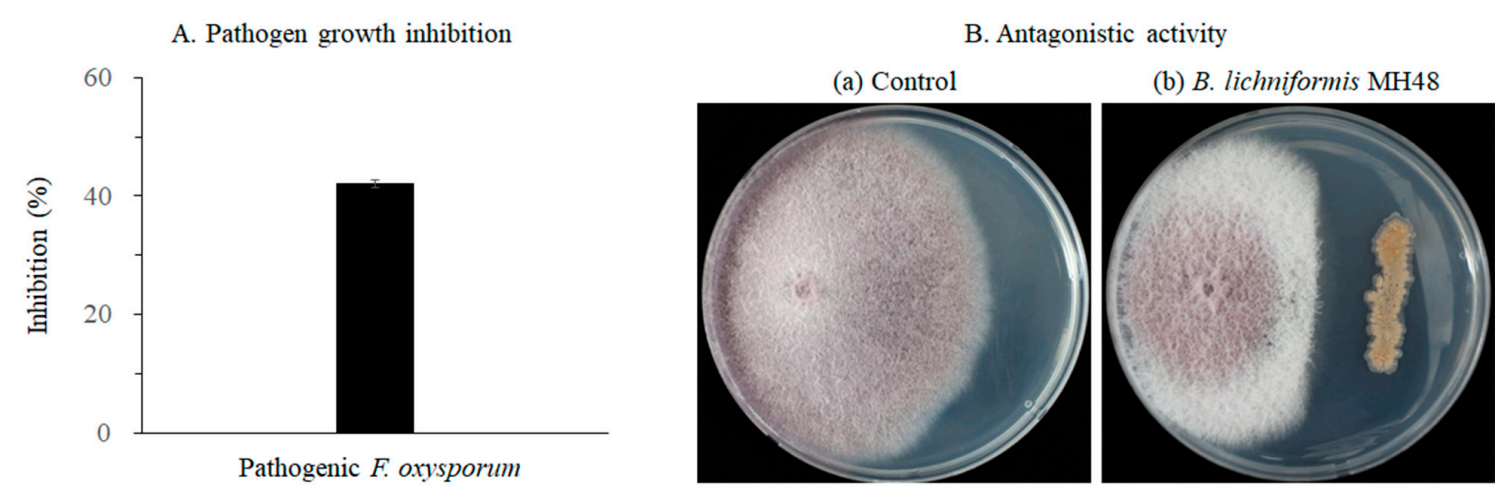

Figure 4. Growth inhibition percentage shown in a graph (A) and antagonistic activity shown in pictures (B) for control (a) and B. licheniformis MH48 (b) against F. oxysporum by culture method.

Large height and well-developed roots in seedlings are the most essential attributes for vigorous growth following outplanting $[10,12]$. Nitrogen and phosphorus are essential nutrients for healthy seedling production [25]. B. licheniformis MH48 can increase the contents of total nitrogen and total phosphorus in soils via fixed atmospheric nitrogen and solubilizing inorganic phosphate $[25,26]$. Nevertheless, the total nitrogen and total phosphorus contents in the growth media were not significantly increased by either inoculation with B. licheniformis MH48 or the chemical fertilizer (Table 1). In particular, the content of total nitrogen in the growth media after treatment with bacterial inoculation was significantly decreased (Table 1). This finding indicates that the seedlings in both bacterial inoculation and chemical fertilizer treatments absorbed sufficient nutrients from the growth media (Table 1) and increased their seedling growth and biomass (Table 2). Especially, B. licheniformis MH48 can produce auxin [25,26], which can stimulate root development (Table 2), resulting in an increased uptake of nutrients, especially total nitrogen, from the growth media (Table 1). Therefore, inoculation with B. licheniformis MH48 may be superior to chemical fertilizer for the growth and yield of container seedlings. Our results indicated that B. licheniformis MH48 prevented the dissemination of F. oxysporum, lowered the virulence of $F$. oxysporum, and obviously promoted the growth of coastal pine seedlings. Therefore, B. licheniformis MH48 is an ideal choice for producing seedlings in a forest nursery. 


\section{Conclusions}

High-quality seedlings, without infection from diseases and with well-developed shoots and roots, are better able to survive extended environmental stresses and produce vigorous growth after outplanting. The incidence of $F$. oxysporum growth was significantly reduced by B. licheniformis $\mathrm{MH} 48$ (Figures 3 and 4), apparently because its enzymes break fungal cell walls (Figure 2). In addition, both the inoculation with $B$. licheniformis MH48 and the use of a chemical fertilizer significantly increased the growth and biomass of coastal pine seedlings, but bacterial inoculation was superior to chemical fertilizer for container seedlings (Table 2). B. licheniformis MH48 shows potential for reducing the need to use chemical fertilizers and for enabling the best soil and seedling management practices to achieve more sustainable forestry. Our study provides a valuable technique that can enable nursery managers to control fungal pathogens and grow sustainable high-quality seedlings by the use of $B$. licheniformis MH48. It is an attractive concept to use PGPR to reduce the need for agrochemicals, reduce disease incidence, and improve seedling growth.

Author Contributions: This study was designed, directed, and coordinated by Y.-S.A., who provided conceptual and technical guidance for all aspects of the project and wrote the manuscript. S.-J.W. was the principal investigator, contributed to the fieldwork and data analysis, performed the literature search, and helped with the writing of the manuscript. V.C. and J.-H.K. assisted with the fieldwork and analysis of data. D.-H.K. helped in data interpretation and commented on the design of the experiments.

Funding: This study was carried out with the support of the R\&D program for Forest Science \& Technology Projects (No. 2018122B10-1820-AB01) provided by the Korea Forest Service (Korea Forestry Promotion Institute). In addition, this research was supported by the Basic Science Research Program through the National Research Foundation (NRF) of Korea, funded by the Ministry of Education, Science and Technology (No. 2018R1D1A1B07050052). It was also partly supported by the Bio-industry Technology Development Program (111056-05) funded by the Ministry of Agriculture, Food, and Rural Affairs, Republic of Korea.

Conflicts of Interest: The authors declare no conflict of interest.

\section{References}

1. Kudoh, T. Coastal disaster prevention forests in Japan. Jpn. Agric. Res. Q. 1983, 19, 55-58.

2. Obase, K.; Cha, J.Y.; Lee, J.K.; Lee, S.Y.; Lee, J.H.; Chun, K.W. Ectomycorrhizal fungal communities associated with Pinus thunbergii in the eastern coastal pine forests of Korea. Mycorrhiza 2009, 20, 39-49. [CrossRef] [PubMed]

3. Obase, K.; Lee, J.K.; Lee, S.Y.; Chun, K.W. Diversity and community structure of ectomycorrhizal fungi in Pinus thunbergii coastal forests in the eastern region of Korea. Mycoscience 2011, 52, 383-391. [CrossRef]

4. Zhu, J.; Gonda, Y.; Yu, L.; Li, F.; Yan, Q.; Sun, Y. Regeneration of a coastal pine (Pinus thunbergii Parl.) forest 11 years after thinning, Niigata, Japan. PLoS ONE 21012, 7, e47593. [CrossRef] [PubMed]

5. Ewane, E.B.; Lee, J.H.; Lee, H.H. Eight-year monitoring of the height growth and survivorship of seedlings of Pinus thunbergii Parl. planted with sand fence and bush hedge protection in a coastal sandy environment in Korea. For. Sci. Technol. 2016, 12, 192-198. [CrossRef]

6. Nateghi, R.; Bricker, J.D.; Guikema, S.D.; Bessho, A. Statistical analysis of the effectiveness of seawalls and coastal Forests in mitigating tsunami impacts in Iwate and Miyagi Prefectures. PLoS ONE 2016, 11, e0158375. [CrossRef] [PubMed]

7. Zielinski, W.J.; Slauson, K.M.; Carroll, C.R.; Kent, C.J.; Kudrna, D.G. Status of American martens in coastal forests of the Pacific states. J. Mammal. 2001, 82, 478-490. [CrossRef]

8. Ensign, S.H.; Mallin, M.A. Stream water quality changes following timber harvest in a coastal plain swamp forest. Water Res. 2001, 35, 3381-3390. [CrossRef]

9. FAO. Integrated Coastal Area Management and Agriculture, Forestry and Fisheries. In Issues, Perspectives, Policy and Planning Process for Integrated Coastal Area Management; Scialabba, N., Ed.; FAO: Rome, Italy, 1998; pp. $1-84$.

10. Tsakaldimi, M.; Zagas, T.; Tsitsoni, T.; Ganatsas, P. Root morphology, stem growth and field performance of seedlings of two Mediterranean evergreen oak species raised in different container types. Plant Soil 2005, 278, 85-93. [CrossRef] 
11. Wilson, E.; Vitols, K.C.; Park, A. Root characteristics and growth potential of container and bare-root seedlings of red oak (Quercus rubra L.) in Ontario, Canada. New For. 2007, 34, 163-176. [CrossRef]

12. Tian, N.; Fang, S.; Yang, W.; Shang, X.; Fu, X. Influence of container type and growth medium on seedling growth and root morphology of Cyclocarya paliurus during nursery culture. Forests 2017, 8, 387. [CrossRef]

13. Heiskanen, J. Effects of compost additive in sphagnum peat growing medium on Norway spruce container seedlings. New For. 2013, 44, 101-118. [CrossRef]

14. Juntunen, M.L.; Hammar, T.; Rikala, R. Leaching of nitrogen and phosphorus during production of forest seedlings in containers. J. Environ. Qual. 2002, 31, 1868-1874. [CrossRef] [PubMed]

15. Youssef, M.M.A.; Eissa, M.F.M. Biofertilizers and their role in management of plant parasitic nematodes. A review. E3 J. Biotechnol. Pharm. Res. 2014, 5, 1-6.

16. Nicolopoulou-Stamati, P.; Maipas, S.; Kotampasi, C.; Stamatis, P.; Hens, L. Chemical pesticides and human health: The urgent need for a new concept in agriculture. Front. Public Health 2016, 4, 148. [CrossRef] [PubMed]

17. Paungfoo-Lonhienne, C.; Yeoh, Y.K.; Kasinadhuni, N.R.P.; Lonhienne, T.G.A.; Robinson, N.; Hugenholtz, P.; Ragan, M.A.; Schmidt, S. Nitrogen fertilizer dose alters fungal communities in sugarcane soil and rhizosphere. Sci. Rep. 2015, 5, 8678. [CrossRef] [PubMed]

18. Lilja, A.; Rikala, R. Effect of uninucleate Rhizoctonia on the survival of outplanted Scots pine and Norway spruce seedlings. For. Pathol. 2000, 30, 109-115. [CrossRef]

19. Lilja, A.; Poteri, M.; Petaisto, R.L.; Rikala, R.; Kurkela, T.; Kasanen, R. Fungal diseases in forest nurseries in Finland. Silva Fenn. 2010, 44, 525-545. [CrossRef]

20. Dar, G.H.; Beig, M.A.; Ahanger, F.A.; Nadeem, A.; Ganai, N.A.; Ahangar, M.A. Management of root rot caused by Rhizoctonia solani and Fusarium oxysporum in blue pine (Pinus wallichiana) through use of fungal antagonists. Asian J. Plant Pathol. 2011, 5, 62-74. [CrossRef]

21. Shah, T.A.; Zargar, M.Y.; Dar, G.H. Interaction of Rhizoctonia solani with ectomycorrhizal inocula on deodar (Cedrus deodara). Appl. Biol. Res. 1999, 1, 103-107.

22. Joshi, K.K.; Kumar, V.; Dubey, R.C.; Maheshwari, D.K. Effect of chemical fertilizer adaptive variants, Pseudomonas aeruginosa GRC2 and Azotobacter chroococcum AC1 on Macrophomena phaseolina causing charcoal rot of Brassica juncea. Korean J. Environ. Agric. 2006, 25, 228-235. [CrossRef]

23. Jung, R.; Ahn, Y.S. Distribution of mercury concentrations in tree rings and surface soils adjacent to a phosphate fertilizer plant in southern Korea. Bull. Environ. Contam. Toxicol. 2017, 99, 253-257. [CrossRef] [PubMed]

24. Probanza, A.; Lucas García, J.A.; Ruiz Palomino, M.; Ramos, B.; Gutiérrez Mañero, F.Z. Pinus pinea L. seedling growth and bacterial rhizosphere structure after inoculation with PGPR Bacillus (B. licheniformis CECT 5106 and B. pumilus CECT 5105). Appl. Soil Ecol. 2002, 20, 75-84. [CrossRef]

25. Park, H.G.; Jeong, M.H.; Ahn, Y.S. Inoculation with Bacillus licheniformis MH48 to improve Camellia japonica seedling development in coastal lands. Turk. J. Agric. For. 2007, 41, 381-388. [CrossRef]

26. Park, H.G.; Lee, Y.S.; Kim, K.Y.; Park, Y.S.; Park, K.H.; Han, H.O.; Park, C.M.; Ahn, Y.S. Inoculation with Bacillus licheniformis MH48 promotes nutrient uptake in seedlings of the ornamental plant Camellia japonica grown in Korean reclaimed coastal lands. Hortic. Sci. Technol. 2017, 35, 11-20. [CrossRef]

27. Esitken, A.; Karlidag, H.; Ercisli, S.; Turan, M.; Sahin, F. The effect of spraying a growth promoting bacterium on the yield, growth and nutrient element composition of leaves of apricot (Prunus armeniaca L. cv. Hacihaliloglu). Aust. J. Agric. Res. 2003, 54, 377-380. [CrossRef]

28. Orhan, E.; Esitken, A.; Ercisli, S.; Turan, M.; Sahin, F. Effects of plant growth promoting rhizobacteria (PGPR) on yield, growth, and nutrient contents in organically growing raspberry. Sci. Hortic. 2006, 111, 38-43. [CrossRef]

29. Barriuso, J.; Ramos Solano, B.; Santamaría, C.; Daza, A.; Gutiérrez Maňero, F.J. Effect of inoculation with putative plant growth-promoting rhizobacteria isolated from Pinus spp. on Pinus pinea growth, mycorrhization and rhizosphere microbial communities. J. Appl. Microbiol. 2008, 102, 1298-1309. [CrossRef] [PubMed]

30. Viterbo, A.; Ramot, O.; Chernin, L.; Chet, I. Significance of lytic enzymes from Trichoderma spp. in the biocontrol of fungal plant pathogens. Antonie Denderleeuw 2002, 81, 549-556. [CrossRef] 
31. Aktuganov, G.; Melentjev, A.; Galimzianova, N.; Khalikova, E.; Korpela, T.; Susi, P. Wide-range antifungal antagonism of Paenibacillus ehimensis IB- $\mathrm{Xb}$ and its dependence on chitinase and $\beta$-1,3-glucanase production. Can. J. Microbiol. 2008, 54, 577-587. [CrossRef]

32. Mao, S.; Lee, S.J.; Hwangbo, H.; Kim, Y.W.; Park, K.H.; Chan, G.S.; Park, R.D.; Kim, K.Y. Isolation and characterization of antifungal substances from Burkholderia sp. culture broth. Curr. Microbiol. 2006, 53, 358-364. [CrossRef] [PubMed]

33. Ko, H.S.; Jin, R.D.; Krishnan, H.B.; Lee, S.B.; Kim, K.Y. Biocontrol ability of Lysobacter antibioticus HS124 against Phytophthora blight is mediated by the production of 4-hydroxyphenylacetic acid and several lytic enzymes. Curr. Microbiol. 2009, 59, 608-615. [CrossRef] [PubMed]

34. Beneduzi, A.; Ambrosini, A.; Passaglia, L.M.P. Plant growth-promoting rhizobacteria (PGPR): Their potential as antagonists and biocontrol agents. Genet. Mol. Biol. 2012, 35, 1044-1051. [CrossRef]

35. Khabbaz, S.; Zhang, L.; Cáceres, L.; Sumarah, M.; Wang, A.; Abbasi, P. Characterisation of antagonistic Bacillus and Pseudomonas strains for biocontrol potential and suppression of damping-off and root rot diseases. Ann. Appl. Biol. 2015, 166, 456-471. [CrossRef]

36. Jamal, Q.; Lee, Y.S.; Jeon, H.D.; Park, Y.S.; Kim, K.Y. Isolation and biocontrol potential of Bacillus amyloliquefaciens Y1 against fungal plant pathogens. Korean J. Soil Sci. Fertil. 2015, 48, 485-491. [CrossRef]

37. Maung, C.E.H.; Choi, T.G.; Nam, H.H.; Kim, K.Y. Role of Bacillus amyloliquefaciens Y1 in the control of Fusarium wilt disease and growth promotion of tomato. Biocontrol Sci. Technol. 2017, 27, 1400-1415. [CrossRef]

38. Zehnder, G.; Kloepper, J.; Yao, C.; Wei, G. Induction of systemic resistance in cucumber against cucumber beetles (Coleoptera, Chrysomelidae) by plant growth-promoting rhizobacteria. J. Econ. Entomol. 1997, 90, 391-396. [CrossRef]

39. Jeong, M.H.; Yang, S.Y.; Lee, Y.S.; Ahn, Y.S.; Park, Y.S.; Han, H.R.; Kim, K.Y. Selection and characterization of Bacillus licheniformis MH48 for the biocontrol of pine wood nematode (Bursaphelenchus xylophilus). J. Korean For. Soc. 2015, 104, 512-518. [CrossRef]

40. Lee, Y.S.; Nguyen, X.H.; Naing, K.W.; Park, Y.S.; Kim, K.Y. Role of lytic enzymes secreted by Lysobacter capsici YS1215 in the control of root-knot nematode of tomato plants. Indian J. Microbiol. 2015, 55, 74-80. [CrossRef]

41. Jeong, M.H.; Lee, Y.S.; Cho, J.Y.; Ahn, Y.S.; Moon, J.H.; Hyun, H.N.; Cha, G.S.; Kim, K.Y. Isolation and characterization of metabolites from Bacillus licheniformis MH48 with antifungal activity against plant pathogens. Microb. Pathog. 2017, 110, 645-653. [CrossRef]

42. Asiegbu, F.O.; Kacprzak, M.; Daniel, G.; Johansson, M.; Stenlid, J.; Manka, M. Biochemical interactions of conifer seedling roots with Fusarium spp. Can. J. Microbiol. 1999, 45, 923-935. [CrossRef]

43. Chanway, C.P.; Holl, F.B. Influence of soil biota on Douglas fir (Pseudotsuga menziesii) seedling growth: The role of rhizosphere bacteria. Can. J. Bot. 1992, 70, 1025-1031. [CrossRef]

44. Chanway, C.P.; Holl, F.B. Growth of outplanted lodgepole pine seedlings 1 year after inoculation with plant growth promoting rhizobacteria. For. Sci. 1994, 40, 238-246. [CrossRef]

45. Chanway, C.P. Differential response of western hemlock from low and high elevations to inoculation with plant growthpromoting Bacillus polymyxa. Soil Biol. Biochem. 1995, 27, 767-775. [CrossRef]

46. Leyval, C.; Berthelin, J. Rhizodeposition and net release of soluble organic compounds by pine and beech seedlings inoculated with rhizobacteria and ectomycorrhizal fungi. Biol. Fertil. Soils 1993, 15, $259-267$. [CrossRef]

47. Close, D.C.; Paterson, S.; Corkrey, R.; McArthur, C. Influences of seedling size, container type and mammal browsing on the establishment of Eucalyptus globulus in plantation forestry. New For. 2010, 39, 105-115. [CrossRef]

48. South, D.B.; Mitchell, R.J. Determining the "optimum" slash pine seedling size for use with four levels of vegetation management on a flatwoods site in Georgia USA. Can. J. For. Res. 1999, 29, 1039-1046. [CrossRef]

49. Cuesta, B.; Villar-Salvador, P.; Puértolas, J.; Jacobs, D.F.; Benayas, J.M.R. Why do large, nitrogen rich seedlings better resist stressful transplanting conditions? A physiological analysis in two functionally contrasting Mediterranean forest species. For. Ecol. Manag. 2010, 260, 71-78. [CrossRef]

50. Skidmore, A.; Dickinson, C. Colony interactions and hyphal interference between Septoria nodorum and phylloplane fungi. Trans. Br. Mycol. Soc. 1976, 66, 57-64. [CrossRef]

51. Lingappa, Y.; Lockwood, J. Chitin media for selective isolation and culture of Actinomycetes. Phytopathology 1962, 52, 317-323. 
52. Liang, Z.C.; Hseu, R.S.; Wang, H.H. Partial purification and characterization of a 1,3- $\beta$-d-glucanase from Ganoderma tsugae. J. Ind. Microbiol. 1995, 14, 5-9. [CrossRef]

53. Kim, S.J.; Kim, Y.K.; Kim, Y.S.; Byoun, J.K.; Lee, S.W. Development of Soil Management Technique for Healthy Seedling Production in the Forest Nursery, 1st ed.; Korea Forest Research Institute: Seoul, Korea, 2012; pp. 57-80. (In Korean)

54. Mulvaney, R.L. Nitrogen Inorganic Forms. In Methods of Soil Analysis: Part 3, Chemical Methods; Spark, D.L., Page, A.L., Helmke, P.A., Loeppert, R.H., Soltanpoor, P.N., Tabatabai, M.A., Johnston, C.T., Sumner, M.E., Eds.; Soil Science Society of America: Madison, WI, USA, 1996; pp. 1123-1184.

(C) 2018 by the authors. Licensee MDPI, Basel, Switzerland. This article is an open access article distributed under the terms and conditions of the Creative Commons Attribution (CC BY) license (http://creativecommons.org/licenses/by/4.0/). 